\title{
Individual plans and coordinated services: an empowering process
}

\author{
Stein Are Aksnes \\ From 5th European Conference on Rare Diseases (ECRD 2010) \\ Krakow, Poland. 13-15 May 2010
}

In Norway there are some 30,000 people with rare hereditary or congenital disorders. For many rare disorders, the needs they have can be a challenge for both the patient, the family and for the service providers. As a user of long-term, coordinated health and/or social services in Norway, you are entitled to an Individual Plan (IP). The right to an IP is not conditional on a particular diagnosis or age, and is mentioned in several Norwegian acts. One service provider (coordinator) has the overall responsibility for each person's IP. To succeed as a coordinator it is essential to establish and maintain a relationship with the user based on trust and respect. An IP contains an outline of your objectives, your resources and the services you require. As a user you have the right to participate throughout the planning process. The users' contribution to the plan is crucial for success. The individual plan should state when the different measures are to be carried out and who is responsible for this. An IP documents your actual situation and your need for measures and services, and it can also provide a basis for applying for services you do not have today. An IP may be a tool for you to reach your goals in life. It is documented that $87 \%$ of the professionals in local authorities and specialist healthcare think the working model with individual plans encourage cooperation between different parts of the services. In Norway there are 16 different state-financed resource centres for people with rare diseases. To date, such services have been established for over 300 diseases. These centres can be important contributors to an individual plan process, in addition to their advisory role to different parts of the help system.

Correspondence: saa@helsedir.no

Norwegian Directorate for Health, Universitetsgata 2, 0130 Oslo, Norway

BfoMed Central @ 2010 Aksnes; licensee BioMed Central Ltd.
Published: 19 October 2010

doi:10.1186/1750-1172-5-S1-05

Cite this article as: Aksnes: Individual plans and coordinated services:

an empowering process. Orphanet Journal of Rare Diseases 2010

5(Suppl 1):05.
Submit your next manuscript to BioMed Central and take full advantage of:

- Convenient online submission

- Thorough peer review

- No space constraints or color figure charges

- Immediate publication on acceptance

- Inclusion in PubMed, CAS, Scopus and Google Scholar

- Research which is freely available for redistribution

Submit your manuscript at www.biomedcentral.com/submit
C Biomed Central 